\title{
Korelacje między religijnością a poczuciem sensu życia młodzieży szkół ponadgimnazjalnych w Poznaniu w świetle koncepcji Viktora E. Frankla i Dirka Hutsebauta
}

\begin{abstract}
Viktor Emil Frankl is considered to be a pioneering researcher into the issue of the meaning of life. He carried out a thorough analysis of the theories of his predecessors, and coined his own existential analysis and logotherapy, which have become some of the most popular trends in psychotherapy. Searching for the sources of the motivation for human action, one cannot ignore the phenomenon of religiosity. Over time, due to progressive secularization, it has become impossible to describe the religiosity of man through the existing categories. David M. Wulff laid the theoretical foundation for a new way of looking at religion. On the basis of Wulff's theories, Dirk Hutsebaut distinguished four approaches to the Christian religion. His model of religiosity enables us to distinguish the types of faith and the ways of thinking about religion, also taking into account non-believers. This article, shows the correlation between religiosity and the sense of meaning of life in adolescents.
\end{abstract}

Keywords: Viktor Emil Frankl, Dirk Hutsebaut, logotherapy, meaning of live, will to meaning, existential analysis, religiousness, adulthood, maturity 


\section{Wstęp}

Z a jednego z czołowych przedstawicieli badań nad zagadnieniem poczucia sensu życia uznaje się Viktora Emila Frankla, lekarza, psychologa i filozofa. Poddał on wnikliwej analizie i konstruktywnej krytyce teorie swoich poprzedników: Zygmunta Freuda, Alfreda Adlera oraz Carla Gustawa Junga. Frankl zarzucając psychoanalizie Freuda jej redukcjonistyczną interpretację, która widziała w człowieku jedynie popędowość, wskazał na znaczenie istniejącej w człowieku sfery duchowej. Stwierdził także niewystarczalność teorii Adlera, który poszukując źródeł motywacji ludzkiego działania, zerwał z biologiczną interpretacją Freuda, doszukując się ich w dążeniu do mocy, władzy i znaczenia. Kierunek stworzony przez Jung bardziej odpowiadał koncepcji Frankla niż klasyczna psychoanaliza. Być może to właśnie fakt, iż dla Junga zjawisko religijności wiązało się ze sferą nieświadomości, co pozbawiało je charakteru transcendentnego, skłonił Frankla do zbudowania teorii nieświadomości duchowej jako efekt niemożności połączenia religijności ze sferą popędową człowieka. Analiza egzystencjalna i logoterapia Frankla stały się jednym ze znaczących kierunków psychoterapii. Jego teorie doczekały się licznych analiz, interpretacji i rozwinięć.

Wyjaśnianie źródeł motywacji ludzkich działań nie byłoby pełne bez uwzględnienia zjawiska religijności, które stanowi przedmiot badań dla wielu dyscyplin naukowych, takich jak teologia, filozofia, historia czy socjologia. Wśród zajmujących się złożoną rzeczywistością problematyki religijnej należy wymienić wspomnianych już Freuda, Junga czy Adlera, ale także Ericha Fromma - niemieckiego filozofa, socjologa, psychologa i psychoanalityka, Abrahama Maslowa - autora teorii hierarchii potrzeb i jednego z przedstawicieli nurtu psychologii humanistycznej oraz Gordona Willarda Allporta - amerykańskiego psychologa i profesora Uniwersytetu Harvarda. To właśnie Fromm, Maslow Allport, jako przedstawiciele ruchu humanistycznego, w odróżnieniu od Freuda, uznawali religię za jedno ze źródeł integracji osobowości, przyczyniających się do realizacji ludzkiego potencjału. Psychologia religii zakłada, że religijność obok aspektów nadprzyrodzonych ma też swoją warstwę naturalną, dlatego może stać się przedmiotem badań empirycznych, którym podlegają takie jej elementy, jak: proces formowania się religijności, struktura i miejsce religijności w osobowości konkretnego człowieka oraz jego postawa wobec rzeczywistości religijnej określanej jako zbiór twierdzeń opisujących związek między człowiekiem a Bogiem. 


\section{Poczucie sensu życia w świetle koncepcji Viktora E. Frankla}

Zagadnienie sensu i wartości należy do podstawowych zainteresowań logoterapii. Za sens życia uważa się twórcze ustosunkowanie się do własnego istnienia i wzięcie losu we własne ręce. To właśnie dążenie do spełnienia sensu swojej egzystencji Frankl przyjął za fundamentalne pojęcie analizy egzystencjalnej i najbardziej charakterystyczny przejaw noodynamiki. Stworzona przez niego analiza egzystencjalna i logoterapia to „[...] jeden z najbardziej znaczących i liczących się w świecie kierunków współczesnej psychoterapii”" Wkład ten był tak znaczący, że psycholog amerykański Gordon Willard Allport nadał mu nazwę „Trzeciej Wiedeńskiej Szkoły Psychoterapii”, po pierwszej - Zygmunta Freuda i drugiej - Alfreda Adlera, których teorie Frankl poddał wnikliwej analizie i konstruktywnej krytyce.

Krytykę błędów popełnionych przez poprzednie szkoły psychologiczne Frankl zaczął od psychoanalizy Freuda. Zachowując obiektywizm, dokonał sprawiedliwej oceny jego wkładu w psychologię głębi. Miał jednocześnie świadomość różnic, jakie występują między psychoanalizą a analizą egzystencjalną. Pierwsza z nich dotyczyła analizy popędowości, druga zaś sensowności ludzkiego życia. Analiza egzystencjalna zakładała ponadto duchową wolność człowieka tam, gdzie psychoanaliza widziała automatyzm. Głównym zarzutem Frankla pod adresem psychoanalizy była redukcjonistyczna interpretacja, która widziała w człowieku jedynie biologiczną naturę, popędowość, a nie brała pod uwagę sfery duchowej, uznając człowieka za pewien rodzaj automatycznego robota sterowanego przez popędy, którym nie może się on przeciwstawić. Frankl zauważył niewystarczalność psychoanalizy w obliczu problemów współczesnego sobie świata, nigdy jednak nie odebrał jej miana fundamentu każdej psychoterapii, o ile, jak każdy fundament, zniknie pod ziemią, by stać się podstawą dla nowego budynku².

Frankl był również następcą Alfreda Adlera. Psychologia indywidualna jego autorstwa, podobnie jak analiza egzystencjalna Frankla, wyrosła na podłożu Freudowskiej psychoanalizy i lat praktyki lekarsko-psychiatrycznej. Adler zrywając z biologiczną interpretacją Freuda, dopatrywał się ich w dążeniu do mocy, władzy i znaczenia w środowisku społecznym. Frankl nie zaprzeczył tej teorii, ograniczył ją jednak jedynie do pojedynczych przypadków - ludzi opanowanych rządzą władzy i znaczenia. Starał się więc odnaleźć bardziej uniwersalną „sprężynę” ludzkiego działania. Frankl znacznie szerzej ujął relacje międzyludzkie, zauważając nie tylko ich podłoże popędowe, ale przede wszystkim duchowo-osobowe. Błędną koncepcję miłości, podaną przez Adlera, uznał za zdegenerowaną formę dążenia do sensu, a dążenie do znaczenia i zaszczytów za zdegenerowaną formę dążenia

${ }^{1}$ M. Wolicki, Człowiek w analizie egzystencjalnej Viktora Emila Frankla, Przemyśl 1986, s. 24.

${ }^{2}$ Por. ibidem, s. 123. 
do osiągnięć. Nie ocenił jej jednak wyłącznie negatywnie i sam często cytował twierdzenia uznane za prawdziwe, np. podkreślanie transcendencji, ukierunkowanie na cele bardziej niż na zaspokajanie popędów, a także zdolność do opierania się wpływom otoczenia.

Trzecim poprzednikiem Frankla był Carl Gustav Jung. Choć z opracowaną przez niego psychologią analityczną Frankl nie podjął tak bezpośredniej polemiki jak w przypadku Freuda czy Adlera, nie oznaczało to jednak, że aprobował wszystkie jej założenia. Było tak prawdopodobnie dlatego, iż psychologia analityczna Junga najbardziej odpowiadała koncepcji Frankla i była mu duchowo najbliższa. Obaj mieli całościowe spojrzenie na psychikę i jej uwarunkowania zarówno w sferze świadomości, jak nieświadomości człowieka. Stworzona przez Junga koncepcja nieświadomości zbiorowej, teoria archetypów oraz symboli religijnych i społecznych zwróciła uwagę Frankla na istnienie nieświadomości duchowej, która stała się jednym z centralnych zagadnień analizy egzystencjalnej. Ze względu na liczne związki analizy egzystencjalnej i klasycznych szkół psychoterapii trudno wytyczyć sztywne granice. Frankl sam stwierdził, że „[...] analiza egzystencjalna jest jak karzeł na ramionach olbrzyma, widzący jednak lepiej i dalej”3.

Droga, która doprowadziła Frankla do zbudowania nowej szkoły psychoterapeutycznej, prowadziła przez jego pracę psychiatry i neurologa, ale także przez dramatyczny okres pobytu w obozach koncentracyjnych w Teresin, Oświęcimiu, Dachau, Kaufering i Turkheim w latach 1942-1945, który zweryfikował jego twierdzenia dotyczące analizy egzystencjalnej i logoterapii, pozwalając na opracowanie nowych twierdzeń opartych na własnym doświadczeniu, które sam nazwał experimentum crucis. W obozie Frankl namacalnie doświadczył, że utrata sensu życia powoduje utratę sił do walki o własne istnienie, a nawet prowadzi do utraty człowieczeństwa. Wtedy też potwierdził, przygotowaną jeszcze przed wojną, teorię o podstawowym dążeniu człowieka - dążeniu do sensu. „Była to jedyna psychoterapia możliwa do zastosowania w obozie. Aby człowiek mógł przeżyć obóz, trzeba mu było pokazać, że to przeżycie ma sens. Doświadczenia obozowe pokazały Franklowi bardzo jasno, że ci, na których czekały jakieś zadania do spełnienia i byli ich świadomi, byli też bardziej zdolni do przeżycia”. Sytuacje graniczne, cierpienia i przejawy podłości ludzkiej, jakie zmuszały Frankla i jego współwięźniów do walki o zachowanie wewnętrznej wolności i osobowej wartości, doprowadziły go do jednego z najważniejszych stwierdzeń analizy egzystencjalnej mówiącego, że „,...] życie ludzkie ma sens, a wtedy ma go we wszelkich okolicznościach, albo nie ma go wcale”5. Doświadczenia obozowe Frankla nadają jego słowom wiarygodności, co trafnie opisał Allport w przedmowie do jednej z jego książek, nazywając go „psychiatrą godnym wysłuchania”.

\footnotetext{
${ }^{3}$ Ibidem, s. 134.

${ }^{4}$ Ibidem, ss. 47-48.

${ }^{5}$ Cyt. za: M. Wolicki Człowiek w analizie egzystencjalnej..., s. 48.
} 
Pojęcie „sen”” ma dwojakie znaczenie: istnienia i egzystencji. Sens istnienia zawiera w sobie pytania bardziej ogólne: dlaczego coś istnieje? Logoterapia natomiast szuka odpowiedzi na pytania dotyczące egzystencji konkretnego człowieka. Frankl podkreślał, że „,...] sens bytu ludzkiego może być tylko konkretny: może się odnosić tylko ad personam i ad situationem (albowiem nie tylko każda poszczególna osoba, ale także każda osobista sytuacja wypełnia swój sens)”“ $\mathrm{i}$ dodaje: „[...] jeżeli w ogóle można się pytać o sens, trzeba się pytać o sens konkretnej osoby i konkretnej sytuacji”’. Odnalezienie i realizację sensu ukrytego w każdej sytuacji Frankl uważał za podstawowe zadanie ludzkiego życia i związanego z nim niepowtarzalnego powołania. Na wykładzie wygłoszonym w 1985 r. z okazji przyznania nagrody im. Oskara Pfistera na dorocznym zjeździe Amerykańskiego Towarzystwa Psychiatrycznego w Dallas w Teksasie twórca logoterapii mówił, że „,...] sens można odnaleźć w życiu dosłownie w każdych okolicznościach, nawet tych niewyobrażalnych dla zwykłego człowieka”. Czasem to właśnie w sytuacjach granicznych i z pozoru bezsensownych, w obliczu tzw. tragicznej trójcy - bólu, winy i śmierci, staje się on najwyraźniejszy. „Sens życia jest również niewspółmierny do sukcesu i powodzenia, jakie człowiek osiąga w życiu”9. Twórca logoterapii zawsze podkreślał wartość osobistej decyzji człowieka. Dla opisania pewnej faktyczności noetycznej używał wówczas pojęcia poczucia sensu. Słowo „poczucie” wskazuje na podmiotowe znaczenie sensu.

\section{Religijność w ujęciu współczesnej psychologii}

Tendencje zmierzające do marginalizacji przedmiotów badań psychologii religii były uwarunkowane wieloma czynnikami, takimi jak kryzys gospodarczy w okresie międzywojnia czy zmiany ideologiczne. Gordon Allport w książce Osobowość i religia tak to ują:

Pisząc w epoce wiktoriańskiej, William James zdecydował się poświęcić zaledwie dwie strony roli seksu w życiu ludzkim, nazywając go eufemistycznie „instynktem miłości”. Jednak żadne tabu nie powstrzymały go od skierowania ogromnego swego geniuszu na napisanie dzieła takiego, jak Doświadczenie religijne. O religii mówił bez zahamowani i z nieprześcignionym talentem. Dzisiaj przeciwnie, psychologowie piszą za szczerością Freuda czy Kinseya o namiętnościach seksualnych ludzi, a rumienią się i popadają w milczenie, kiedy mowa o żarliwości religijnej ${ }^{10}$.

${ }^{6}$ V.E. Frankl, Homo patiens, Pax, Warszawa 1984, s. 64.

7 Ibidem.

${ }^{8}$ V.E. Frankl, Bóg ukryty, Czarna Owca, Warszawa 2013, s. 176.

${ }_{9}$ M. Wolicki, Podstawy filozoficzne analizy egzystencjalnej i logoterapii, Papieski Wydział Teologiczny we Wrocławiu, Wrocław 2001 s. 151.

${ }^{10}$ G.W. Allport, Osobowość i religia, Pax, Warszawa 1988, s. 90. 
Chociaż w obliczu zachodzących przemian kulturowych mówienie o chrześcijańskiej Europie wydać się może przestarzałe, a konflikty na podłożu religijnym, w imię poprawności politycznej, należałoby uznać jedynie za fakt historyczny, analiza tematyki religijnej w świetle psychologii wciąż pozwala wytłumaczyć niektóre procesy zachodzące w społeczeństwie.

Religijność może stać się przedmiotem badań empirycznych, ponieważ obok aspektów nadprzyrodzonych ma też warstwę naturalną. Przedmiotem takich badań staje się wówczas proces formowania się, struktura i miejsce religijności w osobowości konkretnego człowieka i jego ustosunkowanie się do rzeczywistości religii najczęściej rozumianej jako zbiór twierdzeń i zasad opisujących związek między człowiekiem a Bogiem i w jakiś sposób go regulujących. Religijność obejmuje sądy i przekonania dotyczące wymiaru nadprzyrodzonego oraz praktyki religijne. Nie można utożsamiać religijności wyłącznie z przekonaniami lub praktykami religijnymi czy przynależnością do instytucji religijnych. Nie sposób także odizolować religijności od pozostałych treści i dynamizmów życia psychicznego człowieka. Ustosunkowanie się do rzeczywistości religijnej jest zawsze charakterystyczne dla danej jednostki, ponieważ zależy od jej konkretnych cech, a to pociąga za sobą fakt, iż w życiu psychicznym każdego człowieka religijność spełniać będzie trochę inną rolę. Postępująca sekularyzacja spowodowała, że duchowość została zredukowana do zjawiska psychicznego wbrew klasycznej myśli chrześcijańskiej, która uważała ją za trzecią sferę aktywności, obok fizycznej i psychicznej. Człowiekiem, o poglądach którego uważano, że mają charakter świeckiej teologii, a który wywarł największy wpływ na rozwój XX-wiecznej psychologii, był słynny twórca psychoanalizy Zygmunt Freud. Jego zdaniem tak jak kiedyś religia zastąpiła magię, tak psychoanaliza miała zastąpić obumarłą duchowość i stać się wybawieniem dla przygniecionej poczuciem winy ludzkości. Jego pisma miały charakter „quasi-religijnego objawienia o sile popędu seksualnego i potędze nieświadomości”"11. Znaczący wpływ na kształtowanie się psychologii religii miał także Carl Gustav Jung. W opisywanej przez siebie strukturze osobowości ludzkiej duże znaczenie przypisywał nieświadomości osobowej wraz z kompleksami oraz nieświadomości kolektywnej z archetypami, czyli pierwowzorami ludzkich wierzeń, uczuć i działań przejawiających się w formie symboli, które można zauważyć m.in. w szeroko rozumianej twórczości. Dla Junga systemem symboli, który odnosi się do świata archetypów, jest właśnie religia. „Gnostycki charakter myśli szwajcarskiego psychiatry, liczne nawiązania do okultyzmu, religii Wschodu, alchemii i astrologii sprawiły, że jego poglądy wydają się na tle współczesnej psychologii naukowej tajemnicze, a nawet dziwaczne"12. Przełomowym momentem XX-wiecznej psychologii było powstanie teorii ewolucji Darwina, w świetle której zachowania religijne

${ }^{11}$ Z. Golan, Pojęcie religijności w: S. Głaz (red.), Podstawowe zagadnienia psychologii religii, WAM, Kraków 2006, s. 72.

12 Ibidem, s. 73. 
zaczęto interpretować jako dziedziczenie cech. Z biegiem czasu zaczęło rozwijać się behawiorystyczne rozumienie religijności. Jednym z twórców behawioryzmu był Burrhus Frederic Skinner. Twierdził on, że religia jest jedynie tradycyjnym sposobem kontroli zachowań: „[...] jeśli po wystąpieniu zachowania instrumentalnego następuje bodziec wzmacniający, wzrasta prawdopodobieństwo, że owo zachowanie wystąpi ponownie. Jeśli nie pojawi się wzmocnienie, liczba zachowań instrumentalnych będzie powoli maleć” ${ }^{13}$. Skinner uznał, że człowiek staje się pobożny lub niepobożny na tej samej zasadzie, a stosowane dotąd tradycyjne pojęcia religijne, takie jak: wiara, pobożność moralność czy grzeszność, były jedynie sposobem opisu kształtujących się w społeczeństwie zachowań.

Inne podejście do psychologii religii prezentowali amerykańscy przedstawiciele ruchu humanistycznego, m.in. Gordon Allport, Erich Fromm i Abraham Maslow. Allport uznawał religię za jedno ze źródeł integracji osobowości. Fromm do zagadnienia religii i praktyk religijnych podszedł od innej strony. Jego sposób patrzenia na pobożność człowieka wynikał z rozróżnienia tendencji religijnych na autorytatywne i humanistyczne. Twierdził, że

[...] zasadniczym przymiotem religijności autorytatywnej jest posłuszeństwo, a jej grzechem głównym jest nieposłuszeństwo, nie z powodu moralnych walorów boskości, lecz po prostu ze względu na jej kontrolującą władzę. Centrum natomiast religii humanistycznej jest ludzkość i jej potencjał ${ }^{14}$.

Jej celem jest więc osiągnięcie jak największej siły i samourzeczywistnienie, a nie bezsilność i posłuszeństwo. Poglądy Fromma stały się inspiracją dla Maslowa, który od młodości był wojującym ateistą, ale jednocześnie człowiekiem podatnym na mistycyzm i zdolnym do głębokich wzruszeń. Stworzył on pojęcie doświadczeń szczytowych, którymi nazywał różne stany ekstatyczne, bez wiązania ich jednak z jakąkolwiek interpretacją w duchu religijnych tradycji. Tym, co łączy psychologów humanistycznych, jest przypisywanie religii głównej roli w procesie samoaktualizacji. Opisywane przez nich różne typologie religijności: wewnętrzna i zewnętrzna - Allporta, autorytatywna i humanistyczna - Fromma oraz zdolność do doświadczeń szczytowych - Maslowa przyczyniają się do realizacji ludzkiego potencjału.

\section{Religijność w świetle koncepcji Dirka Hutsebauta}

W obliczu postępującej laicyzacji współczesnych społeczeństw zachodnioeuropejskich, psychologowie religii stanęli przed nowymi wyzwaniami opisania religijności człowieka. Używane wcześniej narzędzia do badania religijności

\footnotetext{
13 Ibidem, s. 74.

14 Ibidem, s. 76.
} 
wydały się „zbyt chrześcijańskie” i dla wielu badanych brzmiały obco. Należało opracować takie metody badawcze, które nie opierałyby się bezpośrednio na tradycyjnie zdefiniowanych prawdach religijnych. Teoretyczne podłoże dla nowego sposobu spojrzenia na religijność nakreślił niemiecki psycholog religii David M. Wulff. Podsumował on badane dotychczas sposoby myślenia religijnego i opisał je, umieszczając w przestrzeni dwuwymiarowej.

Pierwszy wymiar, wertykalny, odpowiada włączeniu lub wyłączeniu transcendencji, a drugi dosłownej lub symbolicznej interpretacji religii (wymiar horyzontalny). Powstały w ten sposób wykres opisuje cztery religijne style poznawcze: literalne potwierdzenie, literalne zaprzeczanie, symboliczne odrzucenie oraz symboliczną afirmację. Na podstawie schematu Wulffa belgijski psycholog z Leuven

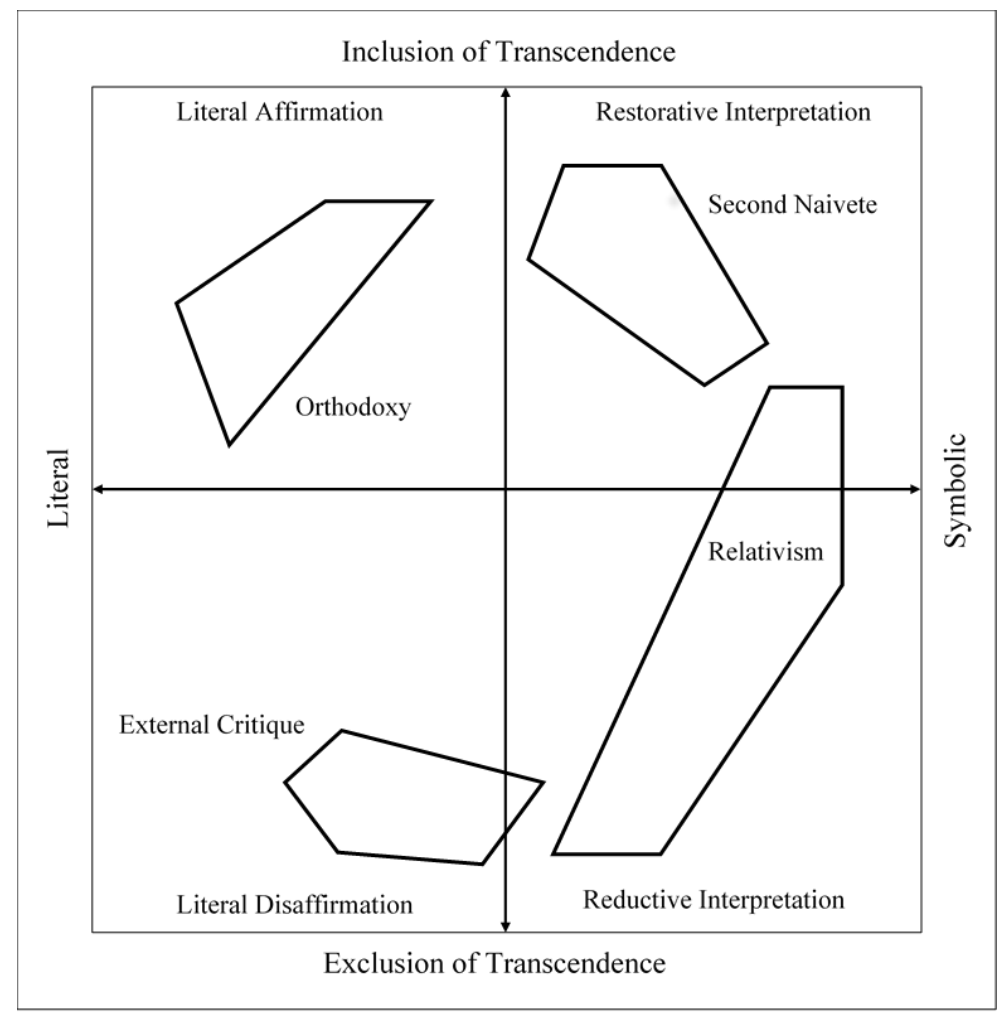

Rysunek 1. Integracja schematu Dirka Hutsebauta ze schematem podsumowującym Davida M. Wulffa

Źródło: B. Duriez, D. Hutsebaut, The relation between religion and racism: The role of post critical beliefs, http://ppw.kuleuven.be/religion/adobe/Religion\&Racism1.pdf [18.07.2010], s. 26; zob. też: B. Duriez, D. Hutsebaut, The relation between religion and racism: The role of post critical beliefs Mental Health, "Religion and Culture" 3/2000, ss. 85-102. 
Dirk Hutsebaut wyróżnił cztery podejścia do religijności chrześcijańskiej: ortodoksję (Orthodoxy), która stanowi miarę literalnej afirmacji; krytykę zewnętrzną (External Critique) - miarę literalnego zaprzeczenia; relatywizm (Relativism), opisujący symboliczne odrzucenie oraz wtórną naiwność (Second Naiveté), która jest miarą afirmacji symbolicznej. To właśnie wtórna naiwność według modelu Wulffa pełni rolę wiodącą. Wysokie wyniki na skali ortodoksji i wtórnej naiwności stanowią wyraz afirmacji wiary chrześcijańskiej. Wysoki wynik na dwóch pozostałych: krytyki zewnętrznej oraz relatywizmu, jest natomiast wyrazem jej odrzucania.

Pierwszy z tych wymiarów, czyli ortodoksja, oznacza wiarę w to, że tylko religia może udzielić prawdziwych odpowiedzi na pytania religijne. Osoba, która uzyska wysoki wynik na skali ortodoksji, będzie przekonana, że każde religijne pytanie ma tylko jedną prawdziwą odpowiedź potwierdzoną przez autorytety i przyjmuje ją, o ile pochodzi od kogoś, kto jest przez nią spostrzegany jako autorytet religijny.

Krytyka zewnętrzna oznacza przyjmowanie raczej postawy niewiary. Wysoki wynik na tej skali jest charakterystyczny dla osób, które twierdzenia o charakterze religijnym interpretują dosłownie, po czym odrzucają ich prawdziwość, odwołując się np. do osiągnięć nauki. Jest to myślenie charakterystyczne dla osób antyreligijnych lub ateistycznych. Oznacza to, że religia w życiu takiej osoby jest ciągle obecna, tyle że w sposób negatywny.

Trzeci wymiar, czyli relatywizm, charakteryzuje osoby, które odrzucają realność przedmiotu religijnego, dążąc do demistyfikacji religii z punktu widzenia niewiary, natomiast przyznają uprzywilejowane miejsce ukrytemu, symbolicznemu znaczeniu mitu religijnego i rytuału, przypisując im doczesne znaczenie. Osoba o takim nastawieniu odmawia realności temu, co transcendentne, odsuwając jedynie do sfery symboli.

Ostatni wymiar, nazywany wtórną naiwnością, charakteryzuje osoby akcentujące istnienie przedmiotu religijnego, jednak religia i treści, które się do niej odnoszą, są przez nie interpretowane w sposób symboliczny. Taka osoba potwierdza realne istnienie Boga, ale unika utożsamiania idei czy pojęć religijnych z realną rzeczywistością, jak to czynią osoby o podejściu ortodoksyjnym. Taka osoba poszukuje metaforycznego znaczenia języka religijnego i symboli. Czytając Pismo Święte, będzie poszukiwała w nim dodatkowego, ukrytego znaczenia, które wykracza poza samą treść. Takie osoby są otwarte na stawienie pytań i nie mają lęków przed nowymi spostrzeżeniami, wykazując się głęboką i osobistą wiarą. Wtórną naiwność można by zaliczyć do dojrzalszych form religijności.

Taki wielowymiarowy model religijności zapowiada odejście od znanych dotąd modeli religijności. Nowa metoda wydaje się dobrze dopasowywać do postępującej laicyzacji współczesnej Europy, a ponadto pozwala różnicować różne typy wiary, a dokładniej - biorąc pod uwagę także osoby uznające się za niewierzące - sposoby myślenia o religii. 


\section{Metodologia badań}

By jak najlepiej opisać zagadnienie religijności i poczucia sensu życia, należy dobrać wypróbowane i rzetelne techniki badawcze dostosowane do polskich warunków.

W badaniach wykorzystano dwie skale: Test Poczucia Sensu Życia (PIL) Jamesa Charlesa Crumbaugha i Leonarda Thomasa Maholicka oraz Skalę Przekonań Postkrytycznych (PCBS) D. Hutsebauta. Test PIL służy do ilościowego określenia poczucia lub braku poczucia sensu życia. Chociaż został stworzony do celów klinicznych, szybko zaczęto korzystać z niego również w badaniach teoretycznych. Test PIL opiera się na założeniach Teorii Victora E. Frankla o poczuciu sensu, które autor uważa za „najgłębszą siłą motywującą egzystencję"15. Test pozwala także wykazać utratę poczucia sensu, która negatywnie wpływa na satysfakcję czerpaną z życia, a w niektórych przypadkach może doprowadzić do nerwicy egzystencjalnej. Polskiej adaptacji testu PIL dokonała Zenomena Płużek. Skala wykorzystywana w pełnej wersji testu składa się z trzech części: ilościowej i jakościowych. W opisywanych badaniach wykorzystana została część ilościowa składająca się z dwudziestu twierdzeń. Do każdego odnosi się 7-stopniowa skala, która określa, w jakim stopniu badany zgadza się, bądź nie, z zaprezentowanym twierdzeniem. Wynik uzyskuje się poprzez zsumowanie odpowiedzi na wszystkie twierdzenia.

Autorami polskiej adaptacji Skali PCBS są Rafał P. Bartczuk, Michał P. Wiechetek i Beata Zarzycka. Najnowsza wersja skali PCBS składa się z 33 pozycji po 8 w skalach ortodoksji, relatywizmu i wtórnej naiwności oraz 9 pozycji w krytyce zewnętrznej. Pozycje są oceniane na 7-punktowej skali Likerta, obejmującej od 1 kompletny sprzeciw (zdecydowanie nie), poprzez 4 - neutralność (nie mam zdania), do 7 - kompletnej zgodności (zdecydowanie tak). Wyniki uzyskane w trakcie badań mieszczą się w przestrzeni dwuwymiarowej. Osoba badana uzyskuje w ten sposób wyniki w czterech skalach: Ortodoksji, Wtórnej naiwności, Krytyki zewnętrznej i Relatywizmu. W przypadku osiągnięcia wysokiego wyniku w jednej ze skal, przy obniżonych rezultatach w pozostałych, można określić dominujący styl myślenia religijnego: literalną afirmację, symboliczną afirmację, literalne zaprzeczenie lub symboliczne zaprzeczenie.

W badaniach posłużono się również autorską ankietą, która składa się z 19 pytań, podzielonych na trzy grupy tematyczne. Część z nich pochodzi ze Skali Praktyk Religijnych (SPR) Władysława Chaima. W wyniku badań przeprowadzonych od marca do maja 2015 r. w Poznaniu uzyskano łącznie 100 kwestionariuszy. Badania zostały przeprowadzone przez katechetów podczas lekcji religii wśród uczniów szkół ponadgimnazjalnych, w skład których weszły technika i licea ogólnokształ-

${ }^{15}$ K. Popielski, Człowiek-pytanie otwarte, Redakcja Wydawnictw KUL, Lublin 1987, s. 135. 
Tabela 1. Średnie (M) i odchylenia standardowe (SD) wyodrębnionych grup

\begin{tabular}{|c|c|c|c|c|c|c|c|}
\hline \multicolumn{2}{|c|}{$\begin{array}{c}\text { RAZEM } \\
100 \text { osób }\end{array}$} & \multicolumn{2}{c|}{$\begin{array}{c}\text { (PLT +) } \\
29 \text { osób }\end{array}$} & \multicolumn{2}{c|}{$\begin{array}{c}\text { (PLT 0) } \\
38 \text { osób }\end{array}$} & \multicolumn{2}{c|}{$\begin{array}{c}\text { (PLT -) } \\
33 \text { osoby }\end{array}$} \\
\hline $\mathrm{M}$ & $\mathrm{SD}$ & $\mathrm{M}$ & $\mathrm{SD}$ & $\mathrm{M}$ & $\mathrm{SD}$ & $\mathrm{M}$ & SD \\
\hline 101,14 & 16,54 & 118,76 & 4,95 & 104,32 & 4,25 & 82,00 & 11,55 \\
\hline
\end{tabular}

Źródło: opracowanie własne.

cące. Grupę badanych stanowiło 66 kobiet i 34 mężczyzn w wieku od 18 do 20 lat. Były to wyłącznie osoby uczęszczające na katechezę, jednak wyniki badań dowiodły, że nie tworzą one grupy tak jednorodnej, jakby się można było spodziewać.

Problemem, który postawiono w badaniach, było pytanie: Czy poczucie sensu życia młodzieży wiąże się z jej religijnością. W związku z tym ogólnym pytaniem nasunęły się pytania bardziej szczegółowe, np.: Jaki w ogóle jest poziom religijności młodzieży? Czy i jak młodzież postrzega zmiany swojej religijności? Czy młodzież dostrzega wpływ środowiska rodzinnego na swoją religijność? Z jakimi obszarami religijności, takimi jak: wychowanie religijne, praktyki religijne, religijne style

Wykres 1 . Autodeklaracja wiary badanych osób $(\mathrm{N}=100)$

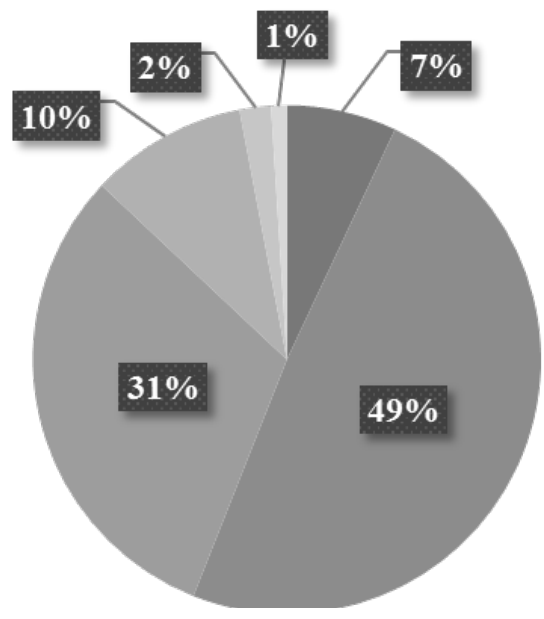

głęboko wierzący/a

- wierzący/a

raczej wierzący/a

obojętny/a

raczej niewierzący/a

niewierzący/a

Źródło: opracowanie własne. 
poznawcze, wiąże się poczucie sensu życia, a z jakimi nie? Ankietowani określali siebie przeważnie jako osoby wierzące.

Uczestnicy badania oceniali swoje poczucie sensu życia za pomocą testu PIL, uzyskując średnią M = 101,14 i odchylenie standardowe SD = 16,54. Na podstawie średniej uporządkowano wszystkie osoby i wyodrębniono trzy grupy: o wysokim poziomie poczucia sensu życia oznaczone w tabeli 1 symbolem (PLT +), o przeciętnym poziomie poczucia sensu życia (PLT 0) i o niskim poziomie poczucia sensu życia (PLT -).

Wykresy 2-5 ilustrują związek między deklarowaną wiarą a poczuciem sensu życia u osób z grup skrajnych: o wysokim i niskim poziomie poczucia sensu życia, a także związek autodeklaracji wiary osób badanych i oceny wiary ich rodziców oraz poczucie zmiany religijności badanych, którzy zostali poproszeni o ocenę temperatury swojej wiary na czterech etapach edukacji.

Najistotniejszych informacji dostarczyło badanie korelacji między religijnością a poziomem poczucia sensu życia u osób badanych. Wykazano, że osoby o wysokiej intensywności poczucia sensu życia charakteryzują się większą dojrzałością w wierze reprezentowaną przez wyższy wynik na skali Wtórnej naiwności, a niższy na skali Zewnętrznej krytyki, zgodnie z opisywanym wcześniej modelem teoretycznym Wulffa.

Wykres 2. Autodeklaracja wiary badanych osób z grup skrajnych o wysokim i niskim poziomie poczucia sensu życia

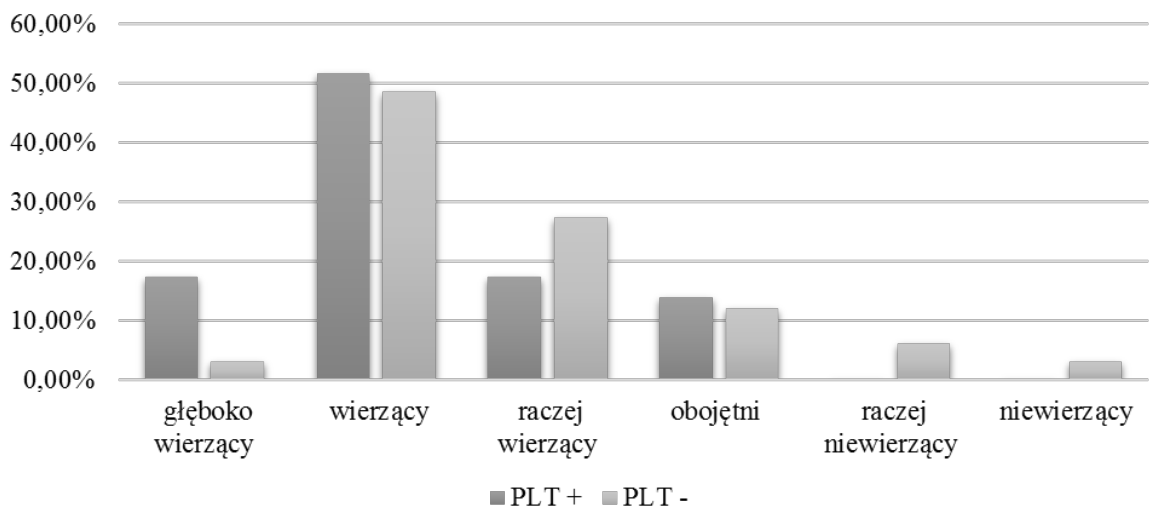

Źródło: opracowanie własne. 
Wykres 3. Autodeklaracja wiary osób badanych a ocena wiary ich rodziców

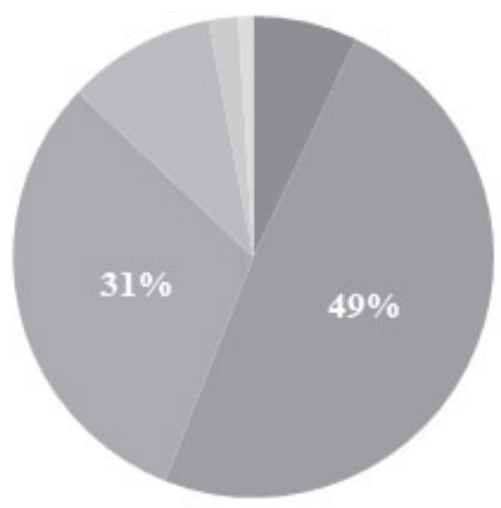
głẹboko wierzacy/a
wierzacy/a
raczej wierzacy/a
obojętny/a
raczej niewierzacy/a
niewierzacy/a

Źródło: opracowanie własne.

Wykres 4. Poczucie stygnięcia wiary na różnych etapach życia osób z wyróżnionych grup o różnym poziomie poczucia sensu życia

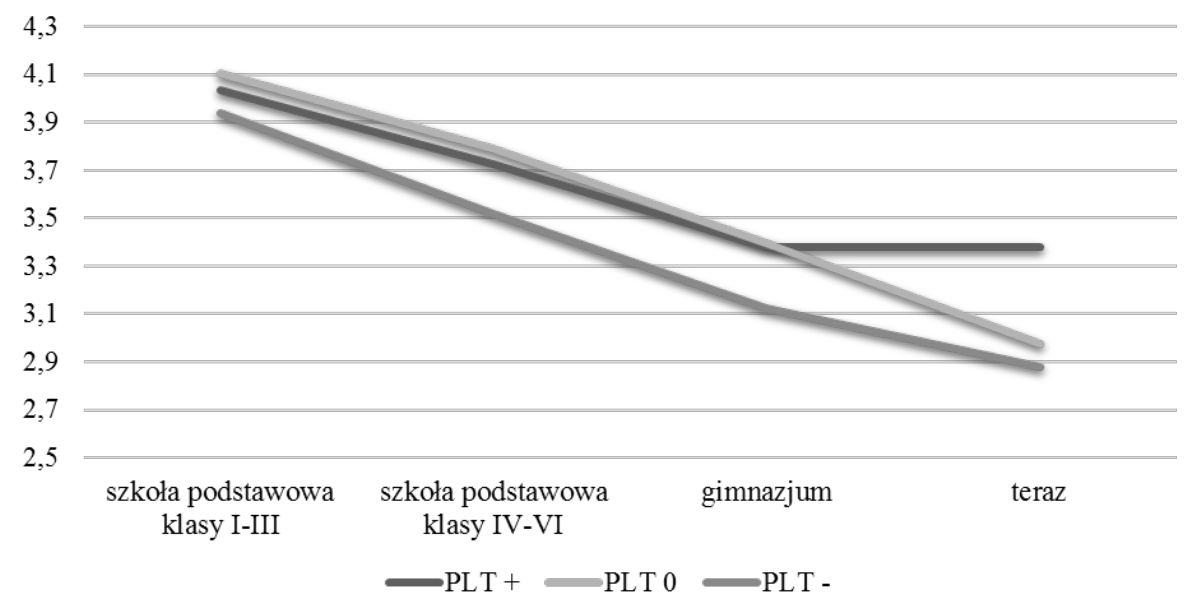

Źródło: opracowanie własne. 
Wykres 5. Korelacje między wynikami PCBS a PIL

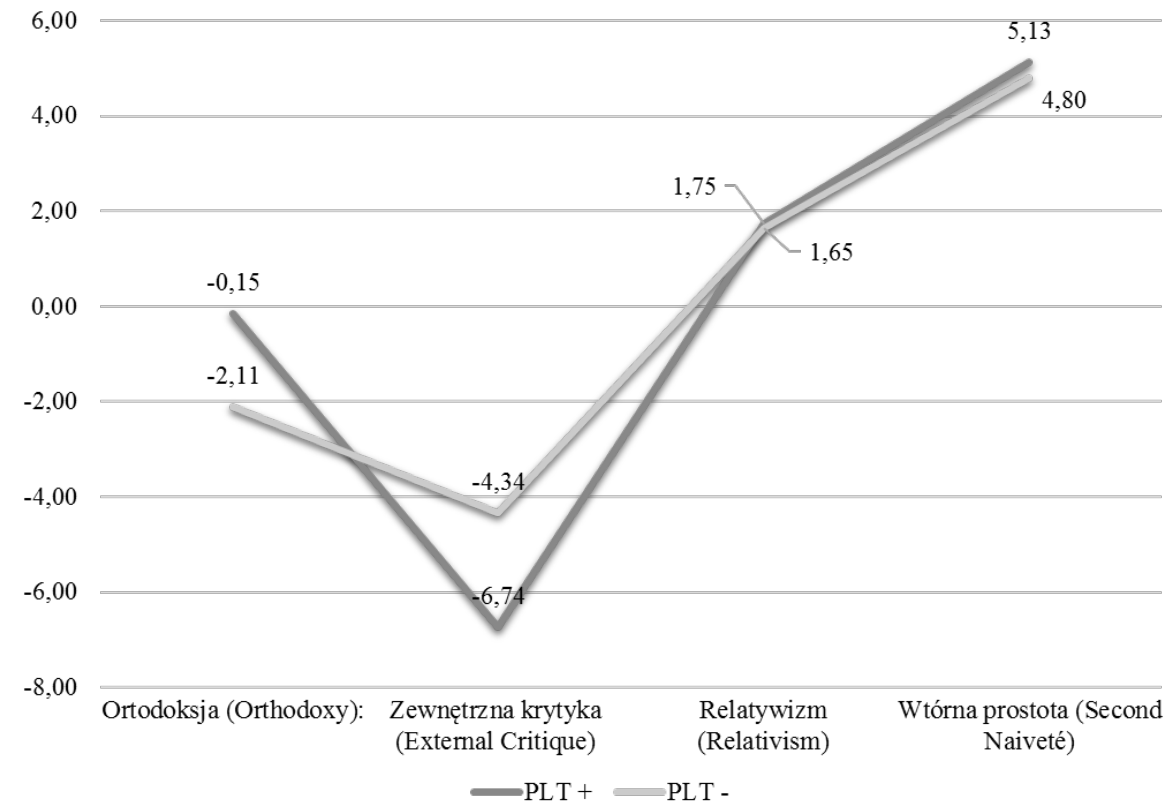

Źródło: opracowanie własne.

\section{Podsumowanie}

W badaniach psychologicznych problematyka sensu życia jest zagadnieniem stosunkowo nowym, zwłaszcza w Polsce. Wśród nich można by wyróżnić badania Rola wartości dla poczucia sensu życia oraz satysfakcji z życia studentów ${ }^{16}$, przeprowadzone przez Marcina Wnuka i Jerzego Tadeusza Marcinkowskiego na Uniwersytecie Medycznym im. Karola Marcinkowskiego w Poznaniu. Badacze doszli do wniosku, że otrzymane rezultaty są w pewnej mierze zgodne z dotychczasowymi wynikami badań, potwierdzając, iż zarówno wartości religijne, jak i duchowe mogą być źródłem sensu życia i w konsekwencji prowadzącym do większej satysfakcji z życia. Innym przykładem mogą być badania Typ religijności

${ }^{16}$ M. Wnuk, J.T. Marcinkowski, Rola wartości dla poczucia sensu życia oraz satysfakcji z życia studentów, „Problemy Higieny Epidemiologii” 91(3)/2010, s. 461. 
a poczucie sensu życia ${ }^{17}$ przeprowadzone przez Małgorzatę Dziurę, które analizowały związki przekonań postkrytycznych z poziomem i wymiarami poczucia sensu życia, a także praca doktorska Michała Wiechetka Interpersonalne korelaty poczucia sensu życia - badania psychologiczne studentów ${ }^{18}$. Liczne prace o opisywanej tematyce powstały także na Wydziale Teologicznym UAM ${ }^{19}$.

Wśród polskich badań nad religijnością młodzieży można by wyróżnić prowadzone przez ks. Mirosława Nowosielskiego badania nad powiązaniami cech osobowości i określonej postaci zaangażowania osoby w kryzys religijny ${ }^{20}$. W podobnych badaniach, choć korzystających z innych skal, Nowosielski opisał korelaty kryzysu religijnego ${ }^{21}$. Innymi zasługującymi na uwagę są badania przeprowadzone w kilku miastach Polski przez Dariusza Kroka²2. Przedmiotem jego badań było m.in.: religijny system znaczeń, hedonistyczna jakość życia, poczucie sensu życia, samoocena i wsparcie społeczne. Na uwagę zasługują także badania prowadzone przez Jacka Śliwaka i Marka Szołdrę dotyczące samoświadomości i religijności u adolescentów ${ }^{23}$. Prowadzone są obecnie rozmaite badania przyczynkarskie, publikowane w czasopismach i seriach wydawniczych ${ }^{24}$. Realizowanych jest wiele

${ }_{17}$ M. Dziura, Typ religijności a poczucie sensu życia (mps pracy magisterskiej), KUL 2006. Zob. R.P. Bartczuk, M.P. Wiechetek, B. Zarzycka, Skala Przekonań Postkrytycznych D. Hutsebauta, w: M. Jarosz (red.), Psychologiczny pomiar religijności, TN KUL, Lublin 2011.

${ }^{18} \mathrm{M}$. Wiechetek, Interpersonalne korelaty poczucia sensu życia - badania psychologiczne studentów (mps pracy doktorskiej), KUL 2008. Zob. M. Jarosz, Skala Personalnej Relacji do Boga, w: M. Jarosz (red.), Psychologiczny pomiar...

19 Zob. B.J. Soiński, Miejsce Eucharystii w życiu modlitewnym osób starszych a poczucie sensu życia, w: A. Jagiełło, B.J. Soiński OFM (red.), Eucharystia w świetle psychologii pastoralnej, Seria: „Edukacja. Teologia i dialog” t. 8, RW WT UAM, Poznań 2011, ss. 157-177; M. Misiak, Modlitwa a poczucie sensu życia u osób w okresie późnej dorosłości, WT UAM 2008 (niepublikowana praca magisterska, mps); K. Celka, Wiara w magię, horoskopy i wróżby a religijność i poczucie sensu życia. Badania młodzieży ze szkół ponadgimnazjalnych, WT UAM, 2016 (niepublikowana praca magisterska, mps).

${ }^{20}$ M. Nowosielski, Korelaty kryzysu religijnego, UKSW, Warszawa 2008. Zob. Skala Kryzysu Religijnego W. Prężyny, w: M. Jarosz (red.), Psychologiczny pomiar...

${ }^{21}$ M. Nowosielski, Korelaty kryzysu religijnego, UKSW, Warszawa 2008. Zob. J. Śliwak, R.P Bartczuk, Skala relacji religijnych - Przeżywane Relacje do Boga D. Hutsebauta, w: M. Jarosz (red.), Psychologiczny pomiar...

${ }^{22}$ D. Krok, Religijność a jakość życia w perspektywie mediatorów psychospołecznych, zob. Skala Religijnego Systemu Znaczeń (SRSZ), w: M. Jarosz (red.), Psychologiczny pomiar...

23 J. Śliwak, M. Szołdra, Samoświadomość a typ religijności - badania empiryczne adolescentów, w: E. Klima, Religion in the time of Changes, University of Łódź (mps.), Department of Space Economy and Spatial Planning, ss. 105-120. Zob. J. Śliwak, R.P. Bartczuk, Skala relacji religijnych...

${ }^{24}$ Zob. D. Musiał, Ujmowanie szczęścia w perspektywie religijnej drugiej osoby przez młodzież, w: E. Rydz, D. Musiał (red.), Z zagadnień psychologii rozwoju człowieka, t. 1, Lublin 2007, ss. 103-125; H. Liberska, Specyfika kształtowania się tożsamości współczesnej młodzieży, w: ibidem, ss. 126-158; H. Liberska, Realizacja zadań rozwojowych a poczucie dobrostanu w średniej dorosłości, w: E. Rydz, D. Musiał (red.), Z zagadnień psychologii rozwoju człowieka, t. 2, Lublin 2008, ss. 250-262.; L. Bakiera, Dylematy średniej dorosłości. Optymistyczne spoj- 
programów badawczych nad rozwojem religijności w ramach seminariów magisterskich na psychologii na KUL, UKSW, jak i na filozofii na PUJP czy w Akademii Ignantianum, a także na wydziałach teologicznych ${ }^{25}$.

W badaniach własnych opisywanych w niniejszym artykule, za pomocą pytań zawartych we wstępnej części ankiety wykazano występowanie pozytywnej zależności zarówno między osobistymi, jak i rodzinnymi praktykami religijnymi badanych a intensywnością poczucia sensu życia, dowodząc również, za pomocą Skali Przekonań Postkrytycznych, że osoby o wysokiej intensywności poczucia sensu życia charakteryzują się większą dojrzałością w wierze reprezentowaną przez wyższy wynik na skali Wtórnej naiwności, a niższy na skali Zewnętrznej krytyki. Należy jednak zauważyć, że choć badania potwierdziły stawiane hipotezy, wykazując związek między religijnością a poczuciem sensu życia, w oparciu o uzyskane wyniki nie można jednoznacznie stwierdzić, iż wysoka intensywność poczucia sensu życia zależy wyłącznie od religijności osób badanych, na co mogłaby wskazywać liczba badanych o skrajnie niskim poczuciu sensu życia, a uznających się za osoby wierzące (wykres 2). Według Frankla, choć sens sam w sobie jest czymś unikatowym - sens konkretnej osoby i konkretnej sytuacji, to samo dążenie do odnalezienia sensu ma charakter uniwersalny, stanowi bowiem „sprężynę” działania wszystkich ludzi: wierzących i tych, co nie wierzą. Owe dążenie do sensu, które Frankl nazwał wolą sensu, jest ściśle związane z dążeniem człowieka do urzeczywistniania wartości. Na początku Frankl używał słów „sens” i „,wartość” jako synonimów, dopiero po jakimś czasie dostrzegł, że dzieli je bardzo wyraźna granica. Pojęcie sensu zarezerwował wówczas dla określenia tego, co ma znaczenie dla konkretnego człowieka w jego sytuacji życiowej, natomiast słowa „wartość” używał dla opisania sensów mających znaczenie bardziej powszechne. Frankl wyróżnił wówczas trzy drogi, na których wartości mogą być realizowane: tworzenia czegoś, doświadczania czegoś i znoszenia czegoś, dzieląc je na wartości twórcze,

rzenie na rodzicielstwo, w: ibidem, ss. 263-280; B. Zarzycka, Religijność a poczucie koherencji u kobiet i mężczyzn w okresie wczesnej dorosłości, w: E. Rydz, D. Musiał (red.), Z zagadnień psychologii rozwoju człowieka, t. 3, Lublin 2010, ss. 105-121.

${ }^{25}$ Na Wydziale Teologicznym UAM obroniono takie prace magisterskie dotyczące psychologicznych aspektów religijności młodzieży, jak: Mariusz Kałas, Wpływ spotkania z Papieżem na religijność młodzieży (badania psychologiczne po IV pielgrzymce do Ojczyzny), Poznań 1995 (mps.); Tomasz Rakoczy, Religijność personalna a postawy wartościujq̨ce u młodzieży klas maturalnych, Poznań 2000 (mps.); Krzysztof Górski, Kryzysy religijne młodzieży w okresie dojrzewania (badania empiryczne), Poznań 2001 (mps.); Marcin Górski, Postawy religijne młodzieży. Badanie empiryczne wychowanków Młodzieżowego Ośrodka Adaptacji Społecznej w Koszalinie, Poznań 2002 (mps.); Łukasz Włodarczak, Temperament a religijność młodzieży maturalnej, Poznań 2011 (mps.); Malwina Wróbel, Zmiany wartościowania i zaangażowania religijnego w dzieciństwie i adolescencji, Poznań 2011 (mps.); Sandra Urny, Uczestnictwo w katechizacji szkolnej i parafialnej a religijność studentów, Poznań 2014 (mps.); Angelika Bartczak, Percepcja zagrożeń życia rodzinnego a religijność młodzieży. Analiza psychologiczno-pastoralna, Poznań 2015. 
przeżyciowe oraz wartości postawy związane głównie ze znoszeniem nieuniknionego cierpienia. Połączenie zagadnienia sensu życia i wiary religijnej jest ścisłe, chociaż nie wyłączne. W nauczaniu teologów ${ }^{26}$ można odnaleźć stwierdzenie, że sens absolutny, czyli taki, który wykracza poza jednostkowe doświadczenie sensu, jest identyczny z Bogiem, a człowiek poszukujący sensu życia w istocie poszukuje Boga niezależnie od tego, czy o tym wie, czy nie. Wychowanie oparte na teorii wartości Frankla może być drogą dotarcia do osób niewierzących, a nawet wrogo nastawionych do religii w ogóle, wobec których należałoby unikać odnoszenia się do tematyki religijnej, jednocześnie przykładem własnego życia doprowadzać do wiary i odkrycia tego, co Frankl uważał za supersens, czyli ostateczny sens przekraczający możliwości intelektualne człowieka.

\section{Literatura}

Allport G.W., Osobowość i religia, Pax, Warszawa 1988.

Frankl V. E., Bóg ukryty, Czarna Owca, Warszawa 2013.

Frankl V. E., Homo patiens, Pax, Warszawa 1984.

Frankl V. E., Nieuświadomiony Bóg, Pax, Warszawa 1978.

Frankl V.E., Człowiek w poszukiwaniu sensu, Czarna Owca, Warszawa 2012.

Golan Z., Pojęcie religijności, w: S. Głaz (red.), Podstawowe zagadnienia psychologii religii, WAM, Kraków 2006.

Jarosz M. (red.), Psychologiczny pomiar religijności, TN KUL, Lublin 2011.

Mariański J., Religia i moralność w świadomości Polaków: zależność czy autonomia?, „Konteksty Społeczne” t. 3, 1(5), TN KUL, Lublin 2015.

Mariański J., Religijna koncepcja sensu życia, „Roczniki Nauk Społecznych” t. XVIII, z. 1, TN KUL, Lublin 1990.

Nowosielski M., Korelaty kryzysu religijnego, Warszawa 2008, UKSW.

Popielski K. (red.), Człowiek - pytanie otwarte, Redakcja Wydawnictw KUL, Lublin 1987.

Soiński B.J., Osobowość a Nawrócenie. Psychologiczno-pastoralna analiza osobowości nawróconych członków zakonów i grup religijnych, Poznań 2010.

Walesa C., Rozwój religijności człowieka w ciqgu całego życia, w: S. Głaz (red.), Podstawowe zagadnienia psychologii religii, WAM, Kraków 2006.

Wnuk M., Marcinkowski J.T., Rola wartości dla poczucia sensu życia oraz satysfakcji z życia studentów, „Problemy Higieny Epidemiologii” 91(3)/2010.

Wolicki M. Człowiek w analizie egzystencjalnej Viktora Emila Frankla, Przemyśl 1986.

Wolicki M., Podstawy filozoficzne analizy egzystencjalnej i logoterapii, Papieski Wydział Teologiczny we Wrocławiu, Wrocław 2001.

${ }^{26}$ Por. J. Mariański, Religijna koncepcja sensu życia, „, Roczniki Nauk Społecznych” t. XVIII, z. 1, Lublin 1990, s. 255. Zob. J. Mariański, Religia i moralność w świadomości Polaków: zależność czy autonomia?, „Konteksty Społeczne” t. 3, 1(5), Lublin 2015, ss. 8-26. 
